\title{
Diachronic and Cross-Cultural Comparison: Toward a Better Understanding of International Fascism
}

\author{
Andreas Umland \\ Department of Political Science, National University of "Kyiv-Mohyla Academy", Kiev \\ E-mail: andreumland@yahoo.com
}

The last two decades have seen a consolidation of 'fascism' as a generic concept. In 1991, Roger Griffin's monograph The Nature of Fascism started a series of important new comparative explorations of the varieties of fascism by a number of scholars who have devoted large parts of their lives to the study of this or that permutation of revolutionary ultra-nationalism. Among the authors of important new cross-cultural studies published in the 1990's and 200o's have been, for instance, Stanley G. Payne, Wolfgang Wippermann, Roger Eatwell, A. James Gregor, and Aristotle Kallis. Some - partly heated debates between these and other researchers in the new century have further helped to sharpen our comprehension of the potentials, problems, and risks of applying 'fascism' to pre-, inter- and post-war political ideas and groups. ${ }^{1}$ If taken together, this new body of literature has, by now, changed the nature of fascist studies. Today the term "fascism" appears - when used by authors familiar with recent analogical reasoning, conceptual improvement and scholarly discussions in our sub-discipline - as sufficiently sharp, and heuristically useful to be broadly and productively applied in empirical analysis. It has found application within the study of extremely anti-egalitarian ideas in a number of fields including comparative politics, contemporary history, political anthropology, and cultural studies.

Twenty years after the publication of Griffin's The Nature of Fascism, the creation of a journal devoted exclusively to this particular notion seems, therefore, justified. The comparative approach announced in the title of the journal should secure scholarly progress in two ways: first, comparative analysis whether according to the Most Similar or Most Different Systems Designs - can

\footnotetext{
1) E.g.: Werner Loh and Wolfgang Wippermann, eds. "Faschismus" - kontrovers. Stuttgart: Lucius \& Lucius, 2003; Roger Griffin, Werner Loh and Andreas Umland, eds. Fascism Past and Present, West and East: An International Debate on Concepts and Cases in the Comparative Study of the Extreme Right. Stuttgart: Ibidem-Verlag, 2006.
} 
be used to control for certain variables, in causal explanation. An explicitly comparative approach should allow scholars to identify more clearly the exact social, political, and cultural determinants of the emergence, growth, and/or decline of fascist movements. Against the background of recent innovation in the definition of generic fascism, it appears, moreover, possible to apply it not merely in synchronic cross-cultural analysis. Within diachronic comparison, one can now also contrast classically fascist with neo-fascist groupings when analyzing, for instance, the fate of young democracies, as has been attempted in first juxtapositions of the decline of the Weimar Republic to the development of post-Soviet Russia. ${ }^{2}$ Such comparison should eventually lead to a disambiguation of the current theoretical models that explain the rise of fascism in rather general terms. It should help answering the question why, when, and exactly how fascism ascends and falls.

Secondly, comparative analysis should help us to both additionally refine the concept of fascism and to further extend its range of full as well as diminished subtypes (the latter referring to instances of proto-, para- or semifascism). In which ways can radical interpretations of the vision of the newborn nation express itself, in different historical situations, against the background of diverging cultural traditions, and in response to varying social contexts? New empirical studies may reveal so-far-unknown varieties of fascist thinking. Or they may disclose seemingly fascist phenomena to be, at best, instances of diminished subtypes of fascism, i.e. classify them as not being fully fascist. Such findings should help us to better understand the notion, range and borders of the concept of generic fascism. When does nationalism turn fascist or become sufficiently extreme to be classified this way? Or, on the contrary: which species of ultra-nationalism should be seen as remaining ultimately non-fascist, i.e. as being insufficiently revolutionary to be covered with the same generic term as Italian Fascism and German Nazism?

Our new journal should provide an exciting platform for scholarly analysis, exchange, and discussion to answer, in an informative way, these and related questions.

\footnotetext{
2) E.g.: Stephen D. Shenfield Russian Fascism: Traditions, Tendencies, Movements. Armonk, NY: M. E. Sharpe, 2001; Stephen E. Hanson Post-Imperial Democracies: Ideology and Party Formation in Third Republic France, Weimar Germany, and Post-Soviet Russia. Cambridge, UK: Cambridge University Press, 2010; Steffen Kailitz and Andreas Umland Why the Fascists Won't Take Over the Kremlin (for Now): A Comparison of Democracy's Breakdown and Fascism's Rise in Weimar Germany and Post-Soviet Russia. Working Paper 14/2010/02 (Moscow: Higher School of Economics, 2010) https://www.hse.ru/data/2010/o6/10/1219754365/WP14_2010_02.pdf.
} 